\title{
Kelekatan dan Kesejahteraan Psikologis Anak dan Remaja: Studi Meta-Analisis
}

\author{
Hepi Wahyuningsih, Resnia Novitasari, Fitri Ayu Kusumaningrum \\ Fakultas Psikologi dan Ilmu Sosial Budaya, Universitas Islam Indonesia, Yogyakarta, Indonesia \\ e-mail: hepi.wahyuningsih@uii.ac.id
}

\begin{abstract}
The purpose of this research is to conduct a meta-analysis study on the attachment with children and adolescents' psychological well-being. In this study, the researchers conducted a metaanalysis of eight groups. The results show that (1) the correlation effect between secure attachment and positive psychological well-being was significant; (2) the correlation effect of secure attachment with negative psychological well-being indicates a significant value; (3) the correlation effect between avoidance and positive psychological well-being was significant; (4) the correlation effect between avoidance and negative psychological well-being was significant; (5) the correlation effect between anxious and positive psychological well-being was not significant; (6) the correlation effect between anxious and negative psychological well-being was significant; (7) the correlation effect between disorganized with positive psychological wellbeing was significant; (8) the correlation effect between disorganized and negative psychological well-being was significant. $Q$ values on all results indicate a high heterogeneity which indicates the presence of a moderator.
\end{abstract}

Keywords: children, adolescents, attachment, psychological well-being

\begin{abstract}
Abstrak
Tujuan penelitian ini ingin melakukan meta analisis terkait hubungan kelekatan dengan kesejahteraan psikologis anak dan remaja. Dalam penelitian ini, peneliti melakukan meta analisis terhadap delapan kelompok studi. Hasil meta-analisis menunjukkan: (1) ukuran efek korelasi antara kelekatan aman dengan kesejahteraan psikologis positif signifikan; (2) ukuran efek korelasi kelekatan aman dengan kesejahteraan psikologis negatif menunjukkan nilai signifikan; (3) ukuran efek korelasi antara kelekatan menghindar (avoidance) dengan kesejahteraan psikologis positif signifikan; (4) ukuran efek korelasi antara kelekatan menghindar (avoidance) dengan kesejahteraan psikologis negatif signifikan; (5) ukuran efek korelasi antara kelekatan cemas (anxious) dengan kesejahteraan psikologis positif signifikan; (6) ukuran efek korelasi antara kelekatan cemas (anxious) dengan kesejahteraan psikologis negatif signifikan; (7) ukuran efek korelasi antara korelasi kelekatan tidak berpola (disorganized) dengan kesejahteraan psikologis positif signifikan; (8) ukuran efek korelasi antara kelekatan tidak berpola (disorganized) dengan kesejahteraan psikologis negatif signifikan. Nilai Q pada semua hasil menunjukkan adanya heterogenitas tinggi yang mengindikasikan adanya moderator.
\end{abstract}

Kata Kunci: anak, remaja, kelekatan, kesejahteraan psikologis

\section{Pendahuluan}

Perkembangan anak akan semakin kompleks sejalan dengan bertambahnya usia. Perkembangan tersebut meliputi perkembangan internal, mulai dari fisik, kognitif, kepribadian, hingga sosioemosional (Hazen dkk., 2008; Ozdemir dkk., 2016). Perkembangan internal tersebut juga diimbangi oleh meluasnya lingkup interaksi sosial, yang terdiri dari teman sebaya, sekolah, peran orang dewasa di luar keluarga, maupun jalinan relasi di media sosial.

Cakupan interaksi sosial yang lebih luas menghadirkan tekanan tersendiri bagi anak dan remaja. Bentuk-bentuk tekanan yang tidak tertangani disinyalir akan berdampak negatif terutama bagi kesehatan mental anak dan remaja. Tekanan yang umum dialami misalnya perundungan (Troop-Gordon, 2017), citra tubuh negatif 
(Voelker dkk., 2015), tekanan teman sebaya (Tomé dkk., 2012; Yavuzer dkk., 2014), maupun tekanan akademik (Arslan, 2017; Chellamuthu \& Kadhiravan, 2017). Apabila tekanan tersebut dalam tingkat tinggi dan patologis, maka kualitas kesehatan mental anak dan remaja akan mengalami penurunan. Dampaknya adalah muncul berbagai jenis permasalahan perilaku, baik permasalahan internalisasi maupun eksternalisasi (Lancefield dkk., 2016).

Upaya pencegahan terhadap permasalahan-permasalahan yang muncul dapat dilakukan dengan meningkatkan kesejahteraan psikologis (Slade, 2010). Kesejahteraan psikologis tidak hanya merujuk pada suatu kondisi yang bebas dari masalah psikologis, tetapi maknanya jauh lebih luas, termasuk kemampuan individu untuk mempersepsikan diri mereka saat berinteraksi dengan orang lain, kemampuan penguasaan lingkungan, kemandirian, dan tujuan hidup serta emosi yang mengarah pada pengembangan secara sehat (Ryff \& Keyes, 1995) .

Terdapat beragam konsep mengenai kesejahteraan psikologis yang dirumuskan oleh beberapa ahli. Silva dkk. (2017) mengemukakan bahwa kesejahteraan psikologis pada remaja melibatkan harga diri dan gangguan depresi. Di sisi lain, Twenge dkk. (2018) mengidentifikasi komponen kesejahteraan psikologis meliputi harga diri, kepuasan hidup, kepuasan diri, dan kebahagiaan. Berikutnya, López dkk. (2018) menyatakan bahwa kesejahteraan psikologis terdiri dari pengaruh positif dan negatif di samping gejala minimum depresi. Sedangkan Liddle dan Carter (2015) mendefinisikan kesejahteraan psikologis pada anak dan remaja sebagai kondisi yang ditandai oleh adanya emosi positif serta penampilan yang positif. Tennant dkk. (2007) merumuskan konsep kesejahteraan psikologis ke dalam konsep positif dan negatif. Berdasarkan paparan tersebut, maka tampak bahwa kesejahteraan psikologis memiliki spektrum. Hal ini ditandai dari kesejahteraan psikologis yang tinggi (positif) yang menunjukkan adanya kebahagiaan atau kepuasan hidup, maupun sebaliknya yakni kondisi yang rendah (negatif) dengan adanya gangguan kesehatan mental.

Hasil berbagai riset menunjukkan bahwa kelekatan orang tua memiliki keterkaitan erat dengan kesejahteraan psikologis anak dan remaja. Bahkan, dalam segala kondisi (baik berkebutuhan khusus/ disabilitas atau tidak) ternyata kelekatan orang tua berperan penting dalam kesejahteraan psikologis mereka (Abubakar dkk., 2013). Kelekatan pada masa kanakkanak akan menghasilkan model kerja internal (internal working model). Model kerja internal ini akan membantu anak dan remaja untuk mengembangkan relasi sosial terutama dengan teman sebayanya (Shomaker \& Furman, 2009). Selain itu, Dubois-Comtois dkk. (2013) merumuskan proses bertahannya kelekatan di masa remaja. Lebih lanjut, Dubois-Comtois dkk. menjelaskan bahwa hubungan kelekatan yang terbentuk di masa kanak-kanak, kemudian dilanjutkan dalam bentuk komunikasi orang tua yang berkaitan secara langsung dengan kelekatan di masa remaja. Hal ini akan dimediasi dengan perkembangan kognitif dan emosional, serta hubungan sosial. Stabilitas kelekatan yang dibangun antara orang tua dan remaja juga dikuatkan melalui kajian literatur dari McConnell dan Moss (2011). Tokoh tersebut menyatakan bahwa walaupun bentuk kelekatan antara remaja berbeda dengan tahap usia sebelumnya, namun remaja tetap memandang orang tua sebagai figur yang memberikan perlindungan dan perawatan.

Masa transisi yang menghadirkan banyak perubahan ternyata cenderung lebih mudah dilalui dengan adanya peran orang tua (Flamm \& Grolnick, 2013). Interaksi orang tua yang menghadirkan kedekatan emosional secara intens dikenal sebagai kelekatan. Berdasarkan pendapat Bowlby, 
kelekatan ini dibangun sejak tahap perkembangan bayi dan terus-menerus menguat seiring dengan pertambahan usia anak (Bretherton, 1992). Dari berbagai hasil riset tersebut ditemukan bahwa orang tua memegang peran penting terutama dalam kualitas interaksinya.

Terdapat dua jenis kelekatan yang umum dipakai dalam kajian Psikologi Perkembangan, yakni kelekatan aman dan tidak aman. Dalam perjalanannya, terdapat beberapa klasifikasi untuk kelekatan di masa kanak-kanak hingga masa dewasa. Untuk masa kanak-kanak, Ainsworth (dalam Benoit, 2004) merumuskan beberapa jenis kelekatan yakni kelekatan aman karena pengasuh sensitif dan konsisten hadir dalam kehidupan anak; kelekatan tidak aman tipe menghindar (insecure avoidant) yakni tidak adanya kedekatan emosional antara pengasuh dan anak karena penolakan pengasuhnya; kelekatan tidak aman tipe resisten (insecure-resistant) yakni kelekatan yang terbangun sebab pengasuh cenderung inkonsisten pengasuhannya, dan kelekatan tidak aman tipe tidak berpola (insecuredisorganized) atau kebingungan dalam menentukan subjek lekatnya. Selanjutnya, klasifikasi tipe tersebut dikembangkan untuk versi usia yang lebih matang oleh Hazan dan Shaver (1987). Dalam deskripsi teorinya tentang kelekatan di masa dewasa, kedua tokoh tersebut membagi jenis kelekatan menjadi tiga bentuk, yakni: kelekatan aman, yang berarti kelekatan yang didasari oleh rasa percaya, bahagia, serta mampu menjalin hubungan sepenuhnya; kelekatan tidak aman tipe menghindar (avoidant), yang ditandai oleh ketakutan akan keintiman, adanya turbulensi emosional selama menjalani hubungan, serta penuh dengan rasa cemburu, dan terakhir adalah kelekatan tidak aman tipe cemas (anxious) ambivalent) yang memandang satu hubungan penuh dengan posesif, obsesif, dan membutuhkan pengakuan secara terusmenerus. Dua klasifikasi tipe tersebut menunjukkan adanya perbedaan bentuk antara masa kanak-kanak dan masa dewasa.

Kelekatan aman menjadi landasan setiap anak untuk mengembangkan rasa percaya pada orang tua sekaligus juga rasa percaya pada lingkungan sekitarnya (Oldfield dkk., 2015). Kelekatan aman juga berkaitan dengan tingginya kemampuan anak untuk mengembangkan strategi coping (Moretti \& Peled, 2004), harga diri remaja (Wilkinson, 2004), maupun dampak positif lainnya dalam jangka panjang (Flaherty \& Sadler, 2011). Selain itu, kelekatan yang aman juga berdampak pada kepuasan hidup (Chen dkk., 2017; He dkk., 2018), serta optimisme dan resiliensi (He dkk., 2018). Dampak dari kelekatan aman ini tampak berkaitan erat dengan parameter kesejahteraan psikologis.

Sebaliknya, kelekatan tidak aman menghambat rasa percaya anak dan menghadirkan banyak permasalahan psikologis di tahap selanjutnya. Masalah yang ditimbulkan dari kelekatan tidak aman antara lain adalah kemungkinan timbulnya depresi (Lee \& Hankin, 2009), kecemasan pada remaja (Colonnesi dkk., 2011; Lee \& Hankin, 2009; Tambelli dkk., 2012), maupun agresivitas baik secara langsung maupun dengan variabel mediator (Brodie dkk., 2018; Mikulincer \& Shaver, 2011), hingga permasalahan emosional dan perilaku (Oldfield dkk., 2015). Oleh sebab itu, kelekatan tidak aman juga menjadi fokus dalam pengembangan kesejahteraan psikologis pada usia remaja.

Namun demikian, masih ada keterbatasan kajian teoretis berkaitan dengan peran kelekatan orang tua terhadap kesejahteraan psikologis anak dan remaja. Sebagian besar riset masih fokus pada penelitian empiris berbasis data di lapangan yang bervariasi tingkat korelasinya. Hasil pemetaan awal oleh peneliti menemukan ada korelasi yang sedang dan tinggi antara kelekatan dengan kesejahteraan psikologis anak dan remaja (Chen dkk., 2017; KimSpoon dkk., 2012; Milan dkk., 2017; Nishikawa dkk., 2010). Akan tetapi, di sisi 
lain ada pula hasil yang menunjukkan tingkat korelasi yang rendah antara kedua variabel tersebut (Jones \& Cassidy, 2014; Liu \& Huang, 2012; Sherman, 2012; Yan dkk., 2017). Selain itu, peneliti juga belum menemukan studi meta-analisis yang mengkaji keterkaitan antara dua variabel tersebut. Oleh sebab itu dibutuhkan adanya kajian meta-analisis untuk merumuskan pola korelasi yang terbentuk antara dua variabel tersebut dari beragam hasil riset sebelumnya.

\section{Metode Penelitian}

\section{Pencarian Literatur}

Pencarian literatur merupakan langkah kedua dalam meta analisis setelah perumusan masalah (Cooper, 2017). Dalam penelitian ini, EBSCO dan ProQuest sebagai database online Ristekdikti yang digunakan untuk pencarian literatur. Dalam studi meta analisis ini, peneliti ingin mengetahui korelasi antara kelekatan dengan kesejahteraan psikologis, sehingga statistik ukuran efek yang digunakan adalah korelasi (r). Kata kunci yang digunakan adalah adolescent, children, attachment, parent, wellbeing. Semua studi primer yang diperoleh kemudian diseleksi kembali berdasarkan kriteria inklusi sebelum dilakukan meta analisis. Literatur yang dicari dibatasi mulai dari tahun 2007 sampai dengan tahun 2019.

Kriteria inklusi dalam penelitian ini yaitu: (1) melaporkan koefisien korelasi (r); (2) melaporkan jumlah subyek penelitian; dan (3) menyertakan anak/ remaja sebagai subjek penelitian. Setelah dilakukan seleksi berdasarkan kriteria inklusi yang ditetapkan, diperoleh 21 studi primer. Adapun artikel-artikel tersebut secara rinci dapat dilihat pada tabel 1 .

\section{Metode Analisis}

Meta analisis dalam penelitian ini merupakan bare-bones meta-analysis, yaitu analisis yang hanya mengoreksi kesalahan pengambilan sampel (Hunter \& Schmidt, 2014). Selain itu, keberadaan variabel moderator juga akan dideteksi dengan melihat heterogenitas, yang dapat dilihat dengan mengacu pada nilai chi-square (Hedges \& Olkin, 1985). Selain itu heterogenitas juga dapat dilihat dari nilai Indeks $\mathrm{I}^{2}$, dimana heterogenitas dikatakan rendah jika $\mathrm{I}^{2} \approx 25 \%$, sedang jika $\mathrm{I}^{2} \approx 50 \%$, dan tinggi ditunjukkan $\mathrm{I}^{2} \approx 75 \%$ (HuedoMedina dkk., 2006). Koefisien korelasi terbobot dihitung dari masing-masing studi. Nilai tingkat kepercayaan (confidence intervals) $95 \%$ dihitung dalam penelitian ini. Selain itu, peneliti juga menghitung fail-safe $\mathrm{N}$ untuk melihat ada tidaknya bias publikasi (Rothstein, 2007). Sedangkan batas nilai fail-safe $N$ untuk mengatakan apakah terjadi bias publikasi atau tidak, peneliti menggunakan tabel dari Fragkos dkk. (2014). Seluruh analisis dilakukan dengan bantuan CMA software versi free trial.

Dalam penelitian ini diperoleh 115 artikel yang berhasil dikumpulkan. Berdasarkan pada kriteria inklusi, terdapat 21 artikel mengenai hubungan kelekatan dengan kesejahteraan psikologis yang dapat digunakan dalam studi meta analisis ini. Hasil penelitian yang berbeda-beda mengenai korelasi antara kelekatan dengan kesejahteraan psikologis remaja diduga karena konsep dan operasionalisasi/ pengukuran yang multidimensional. Oleh karena itu dalam studi meta analisis ini dilakukan pengkategorian untuk mengelompokkan studi-studi yang diperoleh. Berdasarkan data yang diperoleh, variabel kelekatan dikelompokkan menjadi empat, yaitu: kelekatan aman, kelekatan tidak aman tipe menghindar (avoidance), dan kelekatan tidak aman tipe cemas (anxious) serta kelekatan tidak aman tidak berpola (disorganized). Variabel kesejahteraan psikologis dikelompokkan menjadi dua, yaitu kesejahteraan psikologis positif dan kesejahteraan psikologis negatif. Dengan demikian diperoleh delapan kelompok studi yang dianalisis. 
Kelekatan dan Kesejahteraan Psikologis Anak dan Remaja: Studi Meta-Analisis (Hepi Wahyuningsih, Resnia Novitasari, Fitri Ayu Kusumaningrum, Resnia Novitasari)

Tabel 1

Studi yang Digunakan dalam Meta Analisis

\begin{tabular}{|c|c|c|c|c|c|}
\hline No. & Penulis & $\mathbf{N}$ & Subjek & Alat Ukur Kelekatan & Alat Ukur Well-Being \\
\hline 1 & Laghi dkk. (2009) & 2665 & Remaja & $\begin{array}{l}\text { The Inventory of Parent } \\
\text { and Peer Attachment }\end{array}$ & The Basic Psychological Needs Scale \\
\hline 2 & Chung \& Emery (2010) & 454 & Remaja & The Security Scale & Korean Version of Yourh Self Report \\
\hline 3 & Nishikawa dkk.(2010) & 186 & Remaja & $\begin{array}{l}\text { Attachment Questionnaire } \\
\text { for Children }(A Q C)\end{array}$ & $\begin{array}{l}\text { Self-Description Questionnaire } \\
\text { Short;Youth Self-Report }\end{array}$ \\
\hline 4 & Ehrlic dkk. (2011) & 189 & Remaja & $\begin{array}{l}\text { Adult Attachment } \\
\text { Interview }(A A I)\end{array}$ & $\begin{array}{l}\text { The Center for Epidemiologic Studies } \\
\text { Depression Scale;Children's Depression } \\
\text { Inventory Child Behavior }\end{array}$ \\
\hline 5 & Sim \& Yow (2011) & 236 & Remaja & $\begin{array}{l}\text { Attachment to father and } \\
\text { mother by Sim \& Loh }\end{array}$ & $\begin{array}{l}\text { Rosenberg Self-Esteem Scale; the Asian } \\
\text { Adolescent Depression Scale }\end{array}$ \\
\hline 6 & Brenning dkk. (2012) & 238 & Remaja & $\begin{array}{l}\text { Child version of the } \\
\text { Experiences in Close } \\
\text { Relationships Scale- } \\
\text { Revised }\end{array}$ & $\begin{array}{l}\text { the Children's Depression Inventory; the } \\
\text { Youth Self Report and the Child Behavior }\end{array}$ \\
\hline 7 & Delhaye dkk.. (2012) & 152 & Remaja & $\begin{array}{l}\text { Cartes: } \text { Modeles } \\
\text { individuels de relation } \\
\text { (CaMir) }\end{array}$ & $\begin{array}{llc}\text { The Emotional Autonomy } & \text { Scale ; The } \\
\text { Separation-Individuation } & \text { Test } & \text { of } \\
\text { Adolescence } & & \end{array}$ \\
\hline 8 & Eijck dkk. (2012) & 1313 & Remaja & $\begin{array}{l}\text { The Inventory of Parent } \\
\text { and Peer }\end{array}$ & $\begin{array}{l}\text { GAD subscale of the Screen for Child } \\
\text { Anxiety Related Emotional Disorders }\end{array}$ \\
\hline 9 & Kim-Spoon dkk. (2012) & 322 & Remaja & $\begin{array}{l}\text { The Inventory of Parent } \\
\text { and Peer Attachment }\end{array}$ & The Youth Self-Report \\
\hline 10 & Liu \& Huang (2012) & 613 & Remaja & $\begin{array}{l}\text { The Revised Relationship } \\
\text { Questionaire-Adolescents }\end{array}$ & $\begin{array}{l}\text { The Children's Depression Inventory; The } \\
\text { State Trait Anxiety Inventory }\end{array}$ \\
\hline 11 & Sherman (2012) & 12505 & Remaja & $\begin{array}{l}\text { Parental Attachment by } \\
\text { Sherman }\end{array}$ & $\begin{array}{l}\text { The overall delinquency scales; The violent } \\
\text { delinquency measure; The property } \\
\text { delinquency scales }\end{array}$ \\
\hline 12 & $\begin{array}{l}\text { Kullik \& Petermann } \\
(2013)\end{array}$ & 248 & Remaja & $\begin{array}{l}\text { German short version of } \\
\text { the Inventory of Parent } \\
\text { and Peer Attachment }\end{array}$ & $\begin{array}{l}\text { The German version of the Center for } \\
\text { Epidemiological Studies-Depressionscale; } \\
\text { The Regulation of Emotion Questionnaire }\end{array}$ \\
\hline 13 & Jones \& Cassidy (2014) & 99 & Remaja & $\begin{array}{l}\text { Experiences in Close } \\
\text { Relationships Scale }\end{array}$ & $\begin{array}{l}\text { Adolescent Secure Base Use/Maintaining } \\
\text { Secure Relatedness Scale }\end{array}$ \\
\hline 14 & Moreira dkk. (2015) & 171 & $\begin{array}{l}\text { Anak } \\
\text { dan } \\
\text { remaja }\end{array}$ & $\begin{array}{l}\text { The Portuguese version of } \\
\text { the Experiences in Close } \\
\text { Relationships- } \\
\text { Relationship Structures } \\
\text { questionnaire }\end{array}$ & $\begin{array}{l}\text { The Portuguese version of the Self- } \\
\text { Compassion scale }\end{array}$ \\
\hline 15 & Murphy dkk. (2015) & 148 & Remaja & $\begin{array}{l}\text { The Inventory of Parent } \\
\text { and Peer Attachment }\end{array}$ & $\begin{array}{l}\text { the emotionality subscale of the } \\
\text { Emotionality, Activity, and Sociability } \\
\text { Temperament Survey; the Emotion } \\
\text { Regulation Questionnaire; the empathic } \\
\text { concern subscale of the Interpersonal } \\
\text { Reactivity Index }\end{array}$ \\
\hline 16 & Yagon (2015) & 369 & Remaja & Attachment Security Style & $\begin{array}{l}\text { The Negative Affect Factor from the Affect } \\
\text { Scale; The Externalizing/Internalizing } \\
\text { Syndrome Scales from the Standardized } \\
\text { Youth Self-Report Version for Age 11-18 }\end{array}$ \\
\hline 17 & Baytemir (2016) & 462 & Remaja & $\begin{array}{l}\text { Inventory of Parent and } \\
\text { Peer Attachment (IPPA) }\end{array}$ & $\begin{array}{l}\text { Adolescent Subjective Well-being Scale } \\
(\text { ASWS })\end{array}$ \\
\hline 18 & Pace dkk. (2016) & 482 & Remaja & $\begin{array}{l}\text { The Relationship } \\
\text { Questionnaire }\end{array}$ & the Youth Self-Report \\
\hline 19 & Lee \& Park (2017) & 454 & Remaja & $\begin{array}{l}\text { The Inventory of Parent } \\
\text { and Peer Attachment- } \\
\text { Revised }\end{array}$ & Korean version of The Youth Self-Report \\
\hline 20 & Milan dkk. (2017) & 184 & Remaja & $\begin{array}{l}\text { the Behavioral Systems } \\
\text { Questionnaire }\end{array}$ & $\begin{array}{l}\text { The Major Depression subscale from the } \\
\text { Adolescent Psychopathology Scale }\end{array}$ \\
\hline 21 & Yan dkk. (2017) & 150 & $\begin{array}{l}\text { Anak } \\
\text { dan } \\
\text { remaja }\end{array}$ & $\begin{array}{l}\text { Children's report on the } \\
\text { Inventory of Parent and } \\
\text { Peer Attachment }\end{array}$ & $\begin{array}{l}\text { The Center for Epidemiologic Studies } \\
\text { Depression Scale }\end{array}$ \\
\hline
\end{tabular}




\section{Hasil Penelitian dan Pembahasan}

\section{Hasil Analisis}

Hasil analisis dapat dilihat pada tabel 2. Hasil uji heterogenitas perlu dilihat terlebih dahulu. Hasil uji heterogenitas yang tidak signifikan menunjukkan hipotesis null diterima, artinya terdapat homogenitas dalam ukuran efek (effect size). Homogenitas dalam ukuran efek, mengarahkan peneliti untuk menggunakan model fixed effects untuk membaca ukuran efek. Jika hasil uji heterogenitas signifikan, maka terdapat heterogenitas sehingga model yang dipakai untuk membaca ukuran efek dalam random effects model.
Hasil uji heterogenitas korelasi kelekatan aman dengan kesejahteraan psikologis positif menunjukkan nilai signifikan $\left(\mathrm{Q}=218.47 \mathrm{p}<.01, \mathrm{I}^{2}=87.64\right)$, artinya terdapat heterogenitas dalam ukuran efek dari korelasi antara kelekatan aman dengan kesejahteraan psikologis positif yang menunjukkan adanya variabel moderator. Ukuran efek korelasi antara kelekatan aman dengan kesejahteraan psikologis positif signifikan $(\mathrm{r}=.279$; $\mathrm{p}<$ .01) dengan nilai fail-safe $\mathrm{N}$ sebesar 8295 . Nilai fail-safe $\mathrm{N}$ yang sangat besar ini menunjukkan ukuran efek yang diperoleh sangat meyakinkan sehingga dapat dikatakan hampir tidak ada bias publikasi.

Tabel 2

Hasil Meta Analisis

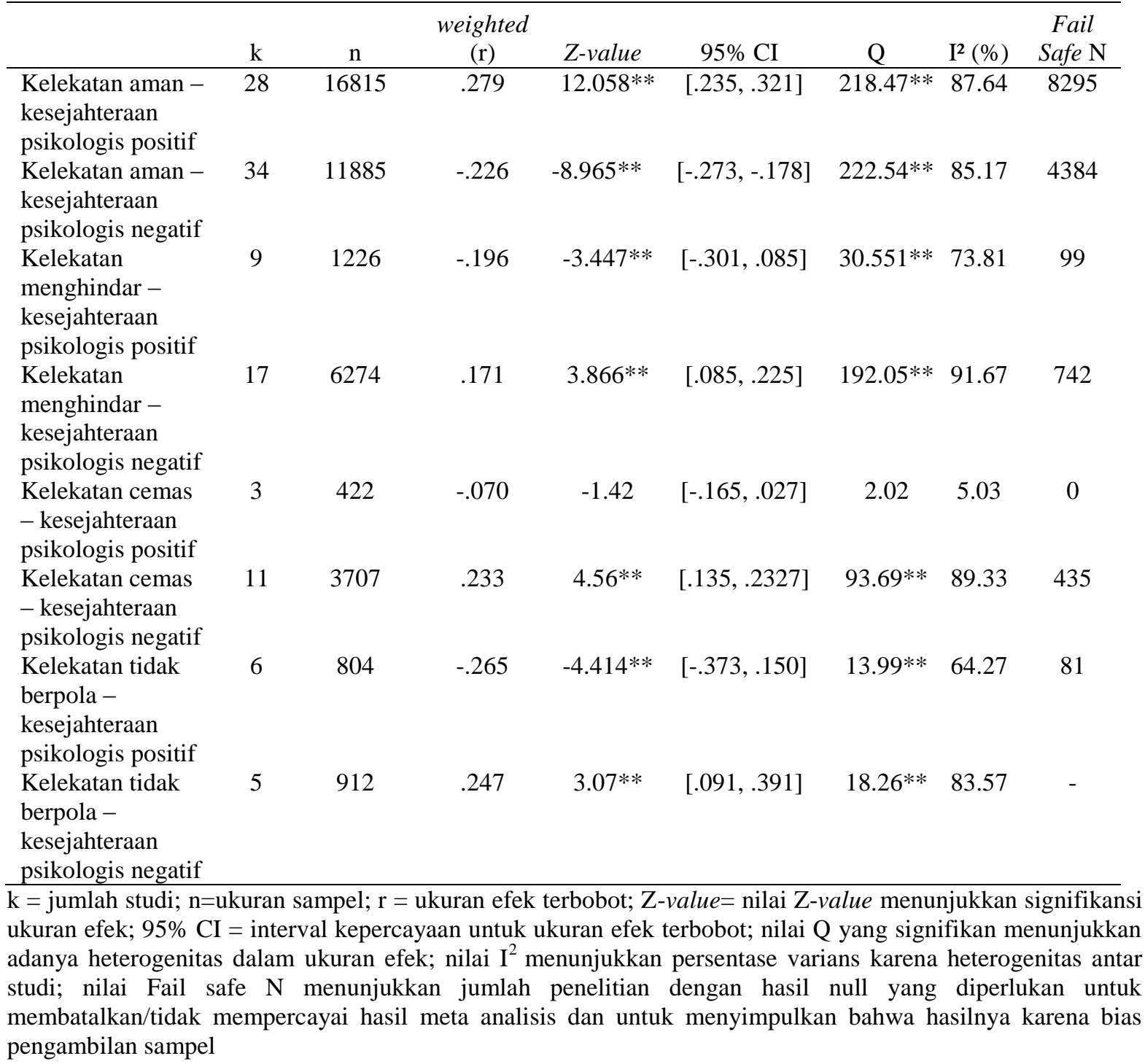


Hasil uji heterogenitas kelekatan aman dengan kesejahteraan psikologis negatif menunjukkan nilai signifikan $(\mathrm{Q}=222.54 \mathrm{p}$ $\left.<.01, \mathrm{I}^{2}=85.17 \%\right)$, artinya terdapat heterogenitas dalam ukuran efek yang menunjukkan adanya variabel moderator. Korelasi kelekatan aman dengan kesejahteraan psikologis negatif menunjukkan nilai signifikan $(\mathrm{r}=-.226 ; \mathrm{p}$ $<.01$; fail-safe $\mathrm{N}=4384$ ). Nilai fail-safe $\mathrm{N}$ yang tinggi menunjukkan ukuran efek yang diperoleh sangat meyakinkan. Meskipun korelasi kelekatan aman dengan kesejahteraan psikologis negatif masih dipengaruhi oleh variabel moderator tetapi memiliki bias publikasi rendah.

Uji heterogenitas korelasi kelekatan tidak aman tipe menghindar (avoidance) dengan kesejahteraan psikologis positif menunjukkan nilai signifikan $(\mathrm{Q}=30.551 \mathrm{p}$ $<.01, \mathrm{I}^{2}=73.81 \%$ ), hal ini menunjukkan terdapat heterogenitas dalam ukuran efek. Ukuran efek korelasi antara kelekatan tidak aman tipe menghindar (avoidance) dengan kesejahteraan psikologis positif signifikan $(\mathrm{r}=-.196 \mathrm{p}<.01 ;$ fail-safe $\mathrm{N}=99)$. Nilai fail-safe $\mathrm{N}$ yang tinggi menunjukkan ukuran efek yang meyakinkan karena memiliki bias publikasi rendah.

Uji heterogenitas korelasi kelekatan tidak aman tipe menghindar (avoidance) dengan kesejahteraan psikologis negatif menunjukkan nilai signifikan $(\mathrm{Q}=192.05 \mathrm{p}$ $<.01, \mathrm{I}^{2}=91.61 \%$ ), hal ini menunjukkan terdapat heterogenitas dalam ukuran efek dan mengindikasikan adanya variabel moderator. Ukuran efek korelasi antara kelekatan tidak aman tipe menghindar (avoidance) dengan kesejahteraan psikologis negatif signifikan $(\mathrm{r}=.171 \mathrm{p}<$ .01; fail-safe $\mathrm{N}=742$ ). Nilai fail-safe $\mathrm{N}$ yang tinggi menunjukkan ukuran efek yang diperoleh sangat meyakinkan karena tidak ada bias publikasi.

Uji heterogenitas korelasi kelekatan tidak aman tipe aman cemas (anxious) dengan kesejahteraan psikologis yang tinggi menunjukkan nilai signifikan $(\mathrm{Q}=$ $\left.2.02 \mathrm{p}<.01, \mathrm{I}^{2}=5.03 \%\right)$, hal ini menunjukkan tidak terdapat heterogenitas dalam ukuran efek dan mengindikasikan tidak ada moderator. Ukuran efek korelasi antara kelekatan tidak aman tipe aman cemas (anxious) dengan kesejahteraan psikologis yang tinggi signifikan $(r=-.070$ $\mathrm{p}<.01$; fail-safe $\mathrm{N}=0$ ). Nilai fail-safe $\mathrm{N}$ yang sangat rendah ini menunjukkan ukuran efek yang diperoleh tidak meyakinkan karena mengandung bias publikasi.

Uji heterogenitas korelasi kelekatan tidak aman tipe cemas (anxious) dengan kesejahteraan psikologis negatif menunjukkan nilai signifikan $(\mathrm{Q}=93.69 \mathrm{p}$ $<.01, \mathrm{I}^{2}=89.33 \%$ ), hal ini menunjukkan adanya heterogenitas dalam ukuran efek dan mengindikasikan adanya moderator. Ukuran efek korelasi antara kelekatan tidak aman tipe cemas (anxious) dengan kesejahteraan psikologis negatif signifikan $(\mathrm{r}=.233 ; \mathrm{p}<.01$; fail safe $\mathrm{N}=435)$. Nilai fail-safe $\mathrm{N}$ yang tinggi menunjukkan ukuran efek yang diperoleh sangat meyakinkan karena tidak ada bias publikasi.

Uji heterogenitas korelasi kelekatan tidak aman tidak berpola (disorganized) dengan kesejahteraan psikologis positif menunjukkan nilai signifikan $(\mathrm{Q}=13.99 \mathrm{p}$ $<.01, \mathrm{I}^{2}=64.27 \%$ ), hal ini menunjukkan terdapat heterogenitas dalam ukuran efek dan mengindikasikan adanya variabel moderator. Ukuran efek korelasi antara korelasi kelekatan tidak aman tidak berpola (disorganized) dengan kesejahteraan psikologis yang tinggi signifikan $(\mathrm{r}=-.265$ $\mathrm{p}<.01$; fail-safe $\mathrm{N}=81$ ). Nilai fail-safe $\mathrm{N}$ yang rendah menunjukkan ukuran efek yang diperoleh kurang meyakinkan karena ada bias publikasi.

Uji heterogenitas korelasi kelekatan tidak aman tidak berpola (disorganized) dengan kesejahteraan psikologis negatif menunjukkan nilai signifikan $(\mathrm{Q}=18.26 \mathrm{p}$ $<.01, \mathrm{I}^{2}=64.27 \%$ ), hal ini menunjukkan terdapat heterogenitas dalam ukuran efek dan ada variabel moderator. Ukuran efek korelasi antara kelekatan tidak aman tidak 
berpola (disorganized dengan kesejahteraan psikologis negatif signifikan ( $\mathrm{r}=.247, \mathrm{p}<$ .01 ; fail-safe $\mathrm{N}=-$ ). Nilai fail-safe $\mathrm{N}$ tidak dapat dihitung karena tidak ada varians.

\section{Pembahasan}

Hasil meta analisis dalam penelitian ini menunjukkan: (1) ukuran efek korelasi antara kelekatan aman dengan kesejahteraan psikologis positif signifikan; (2) ukuran efek korelasi kelekatan aman dengan kesejahteraan psikologis negatif menunjukkan nilai signifikan; (3) ukuran efek korelasi antara kelekatan menghindar (avoidance) dengan kesejahteraan psikologis positif signifikan; (4) ukuran efek korelasi antara kelekatan menghindar (avoidance) dengan kesejahteraan psikologis negatif signifikan; (5) ukuran efek korelasi antara kelekatan cemas (anxious) dengan kesejahteraan psikologis positif tidak signifikan; (6) ukuran efek korelasi antara kelekatan cemas (anxious) dengan kesejahteraan psikologis negatif signifikan; (7) ukuran efek korelasi antara korelasi kelekatan tidak berpola (disorganized) dengan kesejahteraan psikologis positif signifikan; (8) ukuran efek korelasi antara kelekatan tidak berpola (disorganized) dengan kesejahteraan psikologis negatif signifikan.

Ukuran efek terkuat dan signifikan ditemukan pada korelasi antara kelekatan aman dengan kesejahteraan psikologis positif remaja dengan bias publikasi yang rendah yang menunjukkan hasil analisis sangat dapat dipercaya. Hasil ini berbeda dengan hasil meta analisis sebelumnya yang dilakukan oleh Rice (1990) dimana penelitian Rice menemukan kelekatan sehat memiliki ukuran efek moderat dengan penyesuaian diri remaja, tetapi tidak signifikan. Meskipun temuan ini berbeda dengan temuan Rice (1990), tetapi hasil meta analisis ini didukung dari studi-studi yang telah dilakukan sebelumnya oleh para peneliti. Misalnya studi yang dilakukan oleh Laghi dkk. (2009) yang membuktikan bahwa remaja dengan kelekatan positif berkorelasi dengan kebutuhan psikologis dasar yang positif. Studi Nishikawa dkk. (2010) menemukan bahwa kelekatan aman dan harga diri pada remaja perempuan lebih tinggi daripada remaja laki-laki. Studi Baytemir (2016) membuktikan bahwa kelekatan baik pada ayah dan ibu berkorelasi positif signifikan pada afek positif remaja, hubungan dengan orang lain, dan kepuasan hidup. Studi Abubakar dkk. (2013) pada remaja Kenya menjelaskan bahwa peran kelekatan baik pada orang tua dan teman sebaya memainkan peran penting pada pembentukan identitas dan kesejahteraan psikologis remaja.

Ukuran efek yang kuat dan signifikan juga ditemukan dari hasil studi korelasi antara kelekatan tipe tidak berpola dengan kesejahteraan psikologis positif. Akan tetapi bias publikasi yang tinggi menunjukkan hasil ini tidak dapat dipercaya. Bias publikasi dapat disebabkan jumlah studi yang masih sedikit yang ditemukan untuk dilakukan meta analisis dalam penelitian (Basu, 2017). Ukuran efek tidak signifikan ditemukan pada studi yang mencari korelasi antara kelekatan cemas (anxious) dengan kesejahteraan psikologis positif. Akan tetapi hasil ini tidak dapat dipercaya karena memiliki bias publikasi yang tinggi sekali. Bias publikasi tidak dapat dihitung pada korelasi antara kelekatan tidak berpola (disorganized) dengan kesejahteraan psikologis negatif, meskipun hasilnya signifikan, tetapi hasil ini tidak dapat dipercaya.

Secara keseluruhan hasil meta analisis menunjukkan adanya heterogenitas, yang menunjukkan adanya ketidaksamaan/ ketidakseragaman pada studi-studi yang digunakan dalam meta analisis adanya variabel moderator. Apabila dilihat dari studi-studi yang dipakai dalam meta analisis ini, seperti yang tercantum pada tabel 1, heterogenitas dapat terjadi kemungkinan karena bervariasinya alat ukur yang digunakan dalam studi-studi tersebut, selain juga disebabkan masih 
adanya subjek anak-anak yang disertakan dalam penelitian. Seperti yang dikemukakan oleh Viechtbauer (2007) heretogenitas yang didapatkan dalam meta analisis dapat disebabkan oleh bervariasinya metode, prosedur, dan sampel.

Studi kelekatan pada seting yang lebih luas oleh Lucktong dkk. (2017) membuktikan bahwa remaja laki-laki dilaporkan lebih rendah pada kelekatan dengan orang tua. Kelekatan ditemukan mempunyai pengaruh terbesar pada permasalahan internalisasi. Kelekatan dengan orang tua juga berhubungan dengan kepuasan hidup yang mana laki-laki dilaporkan lebih besar tingkat kepuasan hidupnya dibanding wanita. Studi Pan dkk. (2016) pada remaja China menjelaskan bahwa terdapat perbedaan kelekatan ayah dan ibu yang berdampak pada kesehatan psikologis remaja. Kelekatan ayah dinilai lebih kuat berperan pada gejala depresif remaja dibandingkan dengan kelekatan ibu.

Studi oleh Pinto dkk. (2015) membuktikan bahwa secure pada ayah berkorelasi positif dengan harga diri dan peer acceptance. Moreira dkk. (2015) menjelaskan bahwa kelekatan pada ibu secara tidak langsung terkait dengan kualitas hidup anak melalui mediator self compassion dan stres pengasuhan. Ibu yang memiliki kelekatan tipe cemas dan penolakan cenderung berkaitan dengan tingkat kualitas hidup anak yang rendah dan lebih buruk melalui tingkat kasih sayang ibu yang lebih rendah dan tingkat stres pengasuhan yang lebih tinggi.

Studi meta analisis terkait kelekatan dengan depresi pada subjek dewasa telah dilakukan oleh Dagan dkk. (2018). Hasil penelitian mereka membuktikan bahwa kelekatan tidak aman berhubungan dengan gejala depresi pada masa dewasa. Hasil penelitian ini menyarankan dilakukannya penelitian longitudinal dari remaja hingga dewasa untuk menemukan faktor kerentanan. Studi meta analisis terkait kelekatan dan depresi dengan subjek anak hingga remaja juga telah dilakukan oleh Spruit dkk. (2019) yang menemukan bahwa arah hubungan kelekatan aman dan depresi negatif dan kelekatan tidak aman berhubungan positif dengan depresi pada remaja. Studi longitudinal oleh van Eijck dkk. (2012) menemukan bahwa baik kelekatan pada ayah maupun pada ibu, hasilnya berkorelasi negatif signifikan pada depresi remaja.

Studi de Vries dkk. (2016) meneliti kelekatan dengan dimensi kepercayaan, komunikasi, dan kesepian dengan permasalahan perilaku pada remaja. Studi tersebut membuktikan bahwa hubungan kelekatan remaja-orang tua yang buruk dengan agresi dimediasi oleh distorsi kognitif, sedangkan hubungan kelekatan dengan perilaku kenakalan remaja dimediasi oleh faktor sosial, misalnya teman sebaya dan orang tua.

Studi meta analisis terkait kelekatan dengan perilaku bermasalah remaja diteliti oleh Madigan dkk. (2016) pada usia 3-18 tahun. Perilaku internalisasi yang diukur ialah global examining difficulty, kecemasan, dan depresi. Perilaku internalisasi dan eksternalisasi mempunyai ukuran efek yang lebih besar dengan metode pengambilan data melalui pelaporan diri dibandingkan laporan orang tua. Kelekatan ambivalen dan kelekatan menghindar berkorelasi signifikan dengan internalisasi, namun kelekatan ambivalen dan kelekatan menghindar tidak berkorelasi secara signifikan dengan perilaku eksternalisasi. Individu dengan Disorganized attachment cenderung menampilkan perilaku internalisasi lebih tinggi. Disorganized attachment dilaporkan memiliki korelasi dengan perilaku eksternalisasi.

Studi meta analisis oleh Brumariu dkk. (2018) terkait kelekatan menemukan terdapat hubungan negatif signifikan pada kelekatan aman dengan perilaku eksternalisasi dan juga pada perilaku internalisasi. Arah hubungan positif signifikan pada kelekatan aman dengan 
harga diri, kompetensi sosial dan kompetensi emosional. Studi meta analisis Fearon dkk. (2010) terkait kelekatan tidak aman khusus hanya pada perilaku eksternalisasi. Anak dengan kelekatan tidak aman dilaporkan lebih tinggi permasalahan perilaku eksternalisasinya dibandingkan individu dengan kelekatan aman. Kelekatan menghindar berkorelasi positif signifikan dengan perilaku eksternalisasi dan tidak ditemukan efek moderator yang signifikan. Kelekatan tidak aman resisten dengan perilaku eksternalisasi berkorelasi positif namun tidak signifikan, dan tidak ditemukan efek moderator yang signifikan. Kelekatan tidak berpola berkorelasi positif signifikan dengan perilaku eksternalisasi, namun ditemukan gender sebagai moderator.

Studi meta analisis terkait kelekatan tidak aman dan psikopatologi (Goldstein, 2012) menemukan beberapa hasil studi. Kelekatan tidak aman berasosiasi negatif dengan permasalahan perilaku internalisasi dan eksternalisasi. Studi meta analisis oleh Hoeve dkk. (2012) yang meneliti kelekatan dan perilaku kenakalan membuktikan bahwa kelekatan yang buruk berkorelasi signifikan dengan kenakalan remaja perempuan dan laki-laki. Pada ibu, ditemukan bahwa ukuran efek kelekatan lebih kuat dibanding pada ayah. Ditemukan juga efek moderasi meskipun kecil. Ukuran efek lebih kuat ditemukan pada individu yang lebih muda. Studi Groh dkk. (2017) meneliti tentang studi meta analisis terkait kelekatan di awal kehidupan dengan perkembangan sosioemosional.

Hasil riset ini sejalan dengan penelitian sebelumnya dari Cooper dkk. (1998) yang menunjukkan bahwa pola kelekatan tipe cemas ternyata memunculkan permasalahan berupa penyesuaian diri yang rendah dan munculnya perilaku berisiko. Temuan ini sejalan dengan hasil riset sebelumnya. Studi meta analisis oleh Fearon dkk. (2010) terkait kelekatan tidak aman dan perilaku eksternalisasi. Anak dengan kelekatan tidak aman dilaporkan lebih tinggi permasalahan eksternalisasi dibandingkan dengan anak yang berlandaskan pada kelekatan aman. Pada tipe menghindar ternyata berkorelasi positif dan signifikan dengan perilaku eksternalisasi dan tidak ditemukan efek moderator yang signifikan. Selanjutnya, pada kelekatan tipe cemas ternyata berkorelasi positif dengan perilaku eksternalisasi namun tidak signifikan, dan tidak ditemukan efek moderator yang memadai. Penguatan juga didapatkan dari hasil studi meta analisis oleh Hoeve dkk. (2012) yang meneliti kelekatan dan perilaku delinquent membuktikan bahwa bentuk kelekatan yang tidak aman secara signifikan berkorelasi dengan delikuensi pada anak perempuan dan laki-laki.

Konsistensi hasil antara kelekatan tidak aman dengan perilaku internalisasi, ditunjukkan dengan beberapa riset sebelumnya. Misalnya, riset meta analisis dari Colonnesi dkk. (2011) yang menunjukkan bahwa kelekatan tidak aman dalam tingkat menengah berkorelasi dengan kecemasan pada remaja. Hasil riset yang konsisten menunjukkan peran variabel moderator melalui uji heterogenitas juga menarik untuk dikaji. Bentuk kelekatan tidak aman, tidak serta merta akan berperan langsung dalam pembentukan kesejahteraan psikologis negatif. Namun, dinamika tersebut membutuhkan variabel penguat lainnya. Hasil tersebut dikuatkan oleh riset dari Joeng dkk. (2017) yang menemukan bahwa hubungan antara kelekatan tidak aman dengan distress emosional dipengaruhi oleh variabel mediator yakni self-compassion dan ketakutan untuk memberikan selfcompassion. Begitu pula dengan hasil riset dari Lee dan Hankin (2009) yang menemukan bahwa keterkaitan antara kelekatan tipe cemas dengan kecenderungan depresi maupun kecemasan, ternyata dimediasi oleh sikap yang disfungsional dan harga diri yang rendah. 


\section{Simpulan}

Secara umum dapat disimpulkan bahwa berdasarkan studi meta analisis ini menunjukkan kelekatan memiliki korelasi yang signifikan dengan kesejahteraan psikologis remaja. Meskipun demikian, tingkat heterogenitas yang tinggi menunjukkan adanya variabel moderator pada korelasi kelekatan dengan kesejahteraan psikologis yang dapat disebabkan karena variabel moderator seperti jenis kelamin ataupun karena bervariasinya penggunaan alat ukur dalam penelitian. Oleh karena itu untuk penelitian meta analisis selanjutnya dapat menganalisis secara lebih spesifik terkait dengan alat ukur yang digunakan oleh para peneliti.

\section{Daftar Pustaka}

Abubakar, A., Alonso-Arbiol, I., Van de Vijver, F. J. R., Murugami, M., Mazrui, L., \& Arasa, J. (2013). Attachment and psychological wellbeing among adolescents with and without disabilities in Kenya: The mediating role of identity formation. Journal of Adolescence, 36(5), 849857.

https://doi.org/10.1016/j.adolescence. 2 013.05 .006

Arslan, N. (2017). Investigating the relationship between educational stress and emotional self-efficacy. Universal Journal of Educational Research, 5(10), 1736-1740. https://doi.org/10.13189/ujer.2017.051 010

Basu, A. (2017). How to conduct metaanalysis: A basic tutorial. PeerJ Preprints.

https://doi.org/10.7287/peerj.preprints. 2978v1

Baytemir, K. (2016). The mediation of interpersonal competence in the relationship between parent and peer attachment and subjective well-being in adolescence. Education \&
Science/Egitim ve Bilim, 41(186). https://doi.org/https://doi.org/10.15390 /eb.2016.6185

Benoit, D. (2004). Infant-parent attachment: Definition, types, antecedents, measurement and outcome. Paediatrics \& Child Health, 9(8), 541-545. https://doi.org/10.1093/pch/9.8.541

Brenning, K., Soenens, B., Braet, C., \& Bal, S. (2012). The role of parenting and mother-adolescent attachment in the intergenerational similarity of internalizing symptoms. Journal of Youth and Adolescence, 41(6), 802816. https://doi.org/10.1007/s10964011-9740-9

Bretherton, I. (1992). The origins of attachment theory: John Bowlby and Mary Ainsworth. Developmental Psychology, 28(5), 759-775. https://doi.org/10.1037/00121649.28.5.759

Brodie, Z. P., Goodall, K., Darling, S., \& McVittie, C. (2018). Attachment insecurity and dispositional aggression: The mediating role of maladaptive anger regulation. Journal of Social and Personal Relationships, 36(6), 18311852.

https://doi.org/10.1177/026540751877 2937

Brumariu, L. E., Madigan, S., Giuseppone, K. R., Movahed Abtahi, M., \& Kerns, K. A. (2018). The security scale as a measure of attachment: Meta-analytic evidence of validity. Attachment \& Human Development, 20(6), 600-625. https://doi.org/10.1080/14616734.2018 .1433217

Chellamuthu, S., \& Kadhiravan, D. (2017). Academic stress and mental health among high school students. Indian Journal of Applied Research, 7(5), 404-406. https://doi.org/10.36106/IJAR

Chen, W., Zhang, D., Pan, Y., Hu, T., Liu, G., \& Luo, S. (2017). Perceived social support and self-esteem as mediators 
of the relationship between parental attachment and life satisfaction among Chinese adolescents. Personality and Individual Differences, 108, 98-102. https://doi.org/10.1016/j.paid.2016.12. 009

Chung, Y., \& Emery, R. (2010). Early adolescents and divorce in South Korea: Risk, resilience and pain. Journal of Comparative Family Studies, 41(5), 855-870. https://doi.org/10.2307/41604408

Colonnesi, C., Draijer, E. M., Stams, G. J. J. M., Van der Bruggen, C. O., Bögels, S. M., \& Noom, M. J. (2011). The relation between insecure attachment and child anxiety: A meta-analytic review. Journal of Clinical Child and Adolescent Psychology, 40(4), 630645.

https://doi.org/10.1080/15374416.2011 .581623

Cooper, H. (2017). Research synthesis and meta-analysis: A step by step approach (5th ed.). SAGE Publications.

Cooper, M. L., Shaver, P. R., \& Collins, N. L. (1998). Attachment styles, emotion regulation, and adjustment in adolescence. Journal of Personality and Social Psychology, 74(5), 1380 1397. https://doi.org/10.1037//00223514.74.5.1380

Dagan, O., Facompré, C. R., \& Bernard, K. (2018). Adult attachment representations and depressive symptoms: A meta-analysis. Journal of Affective Disorders, 236, 274-290. https://doi.org/10.1016/j.jad.2018.04.0 91

de Vries, S. L. A., Hoeve, M., Stams, G. J. M., \& Asscher, J. (2016). Adolescentparent attachment and externalizing behavior: The mediating role of individual and social factors. Journal of Abnormal Child Psychology, 44(2), 283-294.

https://doi.org/10.1007/s10802-0159999-5

Delhaye, M., Kempenaers, C., Burton, J.,
Linkowski, P., Stroobants, R., \& Goossens, L. (2012). Attachment, parenting, and separation-individuation in adolescence: A comparison of hospitalized adolescents, institutionalized delinquents, and controls. The Journal of Genetic Psychology, 173(2), 119141.

https://doi.org/10.1080/00221325.2011 .594820

Dubois-Comtois, K., Cyr, C., Pascuzzo, K., Lessard, M., \& Poulin, C. (2013). Attachment theory in clinical work with adolescents. Journal of Child \& Adolescent Behavior, 1(3), 1-8. https://doi.org/10.4172/23754494.1000111

Ehrlich, K. B., Cassidy, J., \& Dykas, M. J. (2011). Reporter discrepancies among parents, adolescents, and peers: Adolescent attachment and informant depressive symptoms as explanatory factors. Child Development, 82(3), 999-1012.

https://doi.org/10.1111/j.14678624.2010.01530.x

Fearon, R. P., Bakermans-Kranenburg, M. J., van Ijzendoorn, M. H., Lapsley, A. M., \& Roisman, G. I. (2010). The significance of insecure attachment and disorganization in the development of children's externalizing behavior: A meta-analytic study. Child Development, $\quad 81(2), \quad$ 435-456. https://doi.org/10.1111/j.14678624.2009.01405.x

Flaherty, S. C., \& Sadler, L. S. (2011). A review of attachment theory in the context of adolescent parenting. Journal of Pediatric Health Care: Official Publication of National Association of Pediatric Nurse Associates \& Practitioners, 25(2), 114-121.

https://doi.org/10.1016/j.pedhc.2010.0 2.005

Flamm, E. S., \& Grolnick, W. S. (2013). Adolescent adjustment in the context 
of life change: The supportive role of parental structure provision. Journal of Adolescence, 36(5), 899-912. https://doi.org/10.1016/j.adolescence. 2 013.07.006

Fragkos, K. C., Tsagris, M., \& Frangos, C. C. (2014). Publication bias in metaanalysis: Confidence intervals for Rosenthal's fail-safe number. International Scholarly Research Notices, $\quad 2014, \quad 1-17$. https://doi.org/10.1155/2014/825383

Goldstein, C. (2012). Insecure attachment and psychopathology in children and adolescents: $\quad A$ meta-analysis (Dissertation unpublished). University of Hertfordshire.

Groh, A. M., Narayan, A. J., BakermansKranenburg, M. J., Roisman, G. I., Vaughn, B. E., Fearon, R. M. P., \& van IJzendoorn, M. H. (2017). Attachment and temperament in the early life course: A meta-analytic review. Child Development, 88(3), 770-795. https://doi.org/10.1111/cdev.12677

Hazan, C., \& Shaver, P. (1987). Romantic love conceptualized as an attachment process. Journal of Personality and Social Psychology, 52(3), 511-524. https://doi.org/10.1037/00223514.52.3.511

Hazen, E., Schlozman, S., \& Beresin, E. (2008). Adolescent psychological development: A review. Pediatrics in Review, 29(5), 161-167. https://doi.org/10.1542/pir.29-5-161

He, J., Chen, X., Fan, X., Cai, Z., \& Hao, S. (2018). Profiles of parent and peer attachments of adolescents and associations with psychological outcomes. Children and Youth Services Review, 94, 163-172. https://doi.org/10.1016/j.childyouth.20 18.10.001

Hedges, L. V, \& Olkin, I. (1985). Statistical methods for meta-analysis. Academic Press.

Hoeve, M., Stams, G. J. M., van der Put, C. E., Dubas, J. S., van der Laan, P. H., \&
Gerris, J. R. M. (2012). A metaanalysis of attachment to parents and delinquency. Journal of Abnormal Child Psychology, 40(5), 771-785. https://doi.org/10.1007/s10802-0119608-1

Huedo-Medina, T., Sanchez-Meca, J., Marín-Martínez, F., \& Botella, J. (2006). Assessing heterogeneity in meta-analysis: Q statistic or I 2 Index?. Psychological Methods, 11(2), 193$206 . \quad$ https://doi.org/10.1037/1082989X.11.2.193

Hunter, J., \& Schmidt, F. (2014). Method of meta analysis: Correcting error and bias in reseach findings (2nd ed.). SAGE Publications.

Joeng, J. R., Turner, S. L., Kim, E. Y., Choi, S. A., Kim, J. K., \& Lee, Y. J. (2017). Data for Korean college students' anxious and avoidant attachment, self-compassion, anxiety and depression. Data in Brief, 13, 316319.

https://doi.org/10.1016/j.dib.2017.06.0 06

Jones, J. D., \& Cassidy, J. (2014). Parental attachment style: Examination of links with parent secure base provision and adolescent secure base use. Attachment \& Human Development, 16(5), 437461.

https://doi.org/10.1080/14616734.2014 .921718

Kim-Spoon, J., Longo, G. S., \& McCullough, M. E. (2012). Parentadolescent relationship quality as a moderator for the influences of parents' religiousness on adolescents' religiousness and adjustment. Journal of Youth and Adolescence, 41(12), 1576-1587.

https://doi.org/10.1007/s10964-0129796-1

Kullik, A., \& Petermann, F. (2013). Attachment to parents and peers as a risk factor for adolescent depressive disorders: The mediating role of emotion regulation. Child Psychiatry 
and Human Development, 44(4), 537548. https://doi.org/10.1007/s10578012-0347-5

Laghi, F., D’Alessio, M., Pallini, S., \& Baiocco, R. (2009). Attachment representations and time perspective in adolescence. Social Indicators Research, 90(2), 181-194. https://doi.org/10.1007/s11205-0089249-0

Lancefield, K. S., Raudino, A., Downs, J. M., \& Laurens, K. R. (2016). Trajectories of childhood internalizing and externalizing psychopathology and psychotic-like experiences in adolescence: A prospective populationbased cohort study. Development and Psychopathology, 28(2), 527-536. https://doi.org/10.1017/S09545794150 01108

Lee, A., \& Hankin, B. L. (2009). Insecure attachment, dysfunctional attitudes, and low self-esteem predicting prospective symptoms of depression and anxiety during adolescence. Journal of Clinical Child and Adolescent Psychology, 38(2), 219231.

https://doi.org/10.1080/153744108026 98396

Lee, J. Y., \& Park, S. H. (2017). Interplay between attachment to peers and parents in Korean adolescents' behavior problems. Journal of Child and Family Studies, 26(1), 57-66. https://doi.org/https://doi.org/10.1007/s 10826-016-0552-0

Liddle, I., \& Carter, G. F. A. (2015). Emotional and psychological wellbeing in children: The development and validation of the stirling children's well-being scale. Educational Psychology in Practice, 31(2), 174185.

https://doi.org/10.1080/02667363.2015 .1008409

Liu, Y. L., \& Huang, F. M. (2012). Motheradolescent conflict in Taiwan: Links between attachment style and psychological distress. Social Behavior and Personality: An International Journal, 40(6), 919-931. https://doi.org/10.2224/sbp.2012.40.6.9 19

López, A., Sanderman, R., Ranchor, A. V., \& Schroevers, M. J. (2018). Compassion for others and selfcompassion: Levels, correlates, and relationship with psychological wellbeing. Mindfulness, 9(1), 325-331. https://doi.org/https://doi.org/10.1007/s 12671-017-0777-z

Lucktong, A., Salisbury, T. T., \& Chamratrithirong, A. (2017). The impact of parental, peer and school attachment on the psychological wellbeing of early adolescents in Thailand. International Journal of Adolescence and Youth, 23(2), 235-249. https://doi.org/10.1080/02673843.2017 .1330698

Madigan, S., Brumariu, L. E., Villani, V., Atkinson, L., \& Lyons-Ruth, K. (2016). Representational and questionnaire measures of attachment: A meta-analysis of relations to child internalizing and externalizing problems. Psychological Bulletin, 142(4), 367-399. https://doi.org/10.1037/bul0000029

McConnell, M., \& Moss, E. (2011). Attachment across the life span: Factors that contribute to stability and change. Australian Journal of Educational and Developmental Psychology, 11, 60-77.

Mikulincer, M., \& Shaver, P. R. (2011). Attachment, anger, and aggression. Dalam P. R. Shaver \& M. Mikulincer (Eds.), Herzilya series on personality and social psychology. Human aggression and violence: Causes, manifestations, and consequences. (pp. 241-257). American Psychological Association. https://doi.org/10.1037/12346-013

Milan, S., Wortel, S., Ramirez, J., \& Oshin, L. (2017). Depressive symptoms in 
mothers and daughters: Attachment style moderates reporter agreement. Journal of Abnormal Child Psychology, 45(1), 171-182. https://doi.org/10.1007/s10802-0160156-6

Moreira, H., Gouveia, M. J., Carona, C., Silva, N., \& Canavarro, M. C. (2015). Maternal attachment and children's quality of life: The mediating role of self-compassion and parenting stress. Journal of Child and Family Studies, 24(8), 2332-2344. https://doi.org/10.1007/s10826-0140036-z

Moretti, M. M., \& Peled, M. (2004). Adolescent-parent attachment: Bonds that support healthy development. Paediatrics \& Child Health, 9(8), 551555.

https://doi.org/10.1093/pch/9.8.551

Murphy, T. P., Laible, D. J., Augustine, M., \& Robeson, L. (2015). Attachment's links with adolescents' social emotions: The roles of negative emotionality and emotion regulation. The Journal of Genetic Psychology: Research and Theory on Human Development, 176(5), 315-329. https://doi.org/10.1080/00221325.2015 .1072082

Nishikawa, S., Hägglöf, B., \& Sundbom, E. (2010). Contributions of attachment and self-concept on internalizing and externalizing problems among Japanese adolescents. Journal of Child and Family Studies, 19(3), 334-342. https://doi.org/10.1007/s10826-0099303-9

Oldfield, J., Humphrey, N., \& Hebron, J. (2015). The role of parental and peer attachment relationships and school connectedness in predicting adolescent mental health outcomes. Child and Adolescent Mental Health, 21. https://doi.org/10.1111/camh.12108

Ozdemir, A., Utkualp, N., \& Pallos, A. (2016). Physical and psychosocial effects of the changes in adolescence period. Internasional Journal of Caring Sciences, 9(2), 717-723.

Pace, U., Zappulla, C., \& Di Maggio, R. (2016). The mediating role of perceived peer support in the relation between quality of attachment and internalizing problems in adolescence: a longitudinal perspective. Attachment \& Human Development, 18(5), 508524.

https://doi.org/10.1080/14616734.2016 .1198919

Pan, Y., Zhang, D., Liu, Y., Ran, G., \& Teng, Z. (2016). Different effects of paternal and maternal attachment on psychological health among Chinese secondary school students. Journal of Child and Family Studies, 25(10), 2998-3008. https://doi.org/10.1007/s10826-0160463-0

Pinto, A., Veríssimo, M., Gatinho, A., Santos, A. J., \& Vaughn, B. E. (2015). Direct and indirect relations between parent-child attachments, peer acceptance, and self-esteem for preschool children. Attachment \& Human Development, 17(6), 586-598. https://doi.org/10.1080/14616734.2015 .1093009

Rice, K. G. (1990). Attachment in adolescence: A narrative and metaanalytic review. Journal of Youth and Adolescence, 19(5), 511-538. https://doi.org/10.1007/BF01537478

Rothstein, H. (2007). Publication bias as a threat to the validity of meta-analytic results. Journal of Experimental Criminology, 4(1), 61-81. https://doi.org/10.1007/s11292-0079046-9

Ryff, C., \& Keyes, C. (1995). The structure of psychological well-being revisited. Journal of Personality and Social Psychology, 69(4), 719-727. https://doi.org/10.1037/00223514.69.4.719

Sherman, M. G. (2012). It's a two-way street: The bidirectional relationship 
between parenting and delinquency. Journal of Youth and Adolescence, 41(2), 121-145. https://doi.org/10.1007/s10964-0119656-4

Shomaker, L. B., \& Furman, W. (2009). Parent-adolescent relationship qualities, internal working models, and attachment styles as predictors of adolescents' interactions with friends. Journal of Social and Personal Relationships, 26(5), 579-603. https://doi.org/10.1177/026540750935 4441

Silva, R. N. A., Van de Bongadart, D., Baams, L., \& Raat, H. (2017). Bidirectional associations between adolescents' sexual behaviors and psychological well-being. The Journal of Adolescent Health: Official Publication of the Society for Adolescent Medicine, 62(1), 63-71. https://doi.org/10.1016/j.jadohealth.20 17.08.008

Sim, T. N., \& Yow, A. S. (2011). God attachment, mother attachment, and father attachment in early and middle adolescence. Journal of Religion and Health, 50(2), 264-278. https://doi.org/10.1007/s10943-0109342-y

Slade, M. (2010). Mental illness and wellbeing: The central importance of positive psychology and recovery approaches. BMC Health Services Research, $10, \quad 26$. https://doi.org/10.1186/1472-6963-1026

Spruit, A., Goos, L., Weenink, N., Rodenburg, R., Niemeyer, H., Stams, G. J., \& Colonnesi, C. (2019). The relation between attachment and depression in children and adolescents: A multilevel meta-analysis. Clinical Child and Family Psychology Review, 23(1), 54-69. https://doi.org/10.1007/s10567-01900299-9

Tambelli, R., Laghi, F., Odorisio, F., \&
Notari, V. (2012). Attachment relationships and internalizing and externalizing problems among Italian adolescents. Children and Youth Services Review, 34(8), 1465-1471. https://doi.org/10.1016/j.childyouth.20 12.04.004

Tennant, R., Hiller, L., Fishwick, R., Platt, S., Joseph, S., Weich, S., Parkinson, J., Secker, J., \& Stewart-Brown, S. (2007). The Warwick-Edinburgh Mental Well-being Scale (WEMWBS): Development and UK validation. Health and Quality of Life Outcomes, 5, 63. https://doi.org/10.1186/14777525-5-63

Tomé, G., Matos, M., Simões, C., Diniz, J. A., \& Camacho, I. (2012). How can peer group influence the behavior of adolescents: Explanatory model. Global Journal of Health Science, 4(2), 26-35. https://doi.org/10.5539/gjhs.v4n2p26

Troop-Gordon, W. (2017). Peer victimization in adolescence: The nature, progression, and consequences of being bullied within a developmental context. Journal of Adolescence, 55, 116-128. https://doi.org/10.1016/j.adolescence. 2 016.12.012

Twenge, J. M., Martin, G. N., \& Campbell, W. K. (2018). Decreases in psychological well-being among American adolescents after 2012 and links to screen time during the rise of smartphone technology. Emotion, $18(6)$, 765-780. https://doi.org/10.1037/emo0000403

van Eijck, F. E. A. M., Branje, S. J. T., Hale, W. W., \& Meeus, W. H. J. (2012). Longitudinal associations between perceived parent-adolescent attachment relationship quality and generalized anxiety disorder symptoms in adolescence. Journal of Abnormal Child Psychology, 40(6), 871-883. https://doi.org/10.1007/s10802-0129613-z 
Viechtbauer, W. (2007). Accounting for heterogeneity via random-effects models and moderator analyses in meta-analysis. Zeitschrift Für Psychologie / Journal of Psychology, 215(2), 104-121. https://doi.org/10.1027/00443409.215.2.104

Voelker, D. K., Reel, J. J., \& Greenleaf, C. (2015). Weight status and body image perceptions in adolescents: Current perspectives. Adolescent Health, Medicine and Therapeutics, 6, 149158. https://doi.org/10.2147/AHMT.S68344

Wilkinson, R. B. (2004). The role of parental and peer attachment in the psychological health and self-esteem of adolescents. Journal of Youth and Adolescence, 33(6), 479-493. https://doi.org/10.1023/B:JOYO.00000 48063.59425 .20
Yagon, M. (2015). Externalizing and internalizing behaviors among adolescents with learning disabilities: Contribution of adolescents' attachment to mothers and negative affect. Journal of Child and Family Studies, 24(5), 1343-1357. https://doi.org/10.1007/s10826-0149942-3

Yan, J., Han, Z. R., Tang, Y., \& Zhang, X. (2017). Parental support for autonomy and child depressive symptoms in middle childhood: The mediating role of parent-child attachment. Journal of Child and Family Studies, 26(7), 1970-1978. https://doi.org/10.1007/s10826-0170712-X

Yavuzer, Y., Karatas, Z., Civilidag, A., \& Gundogdu, R. (2014). The role of peer pressure, automatic thoughts and selfesteem on adolescents' aggression. Eurasian Journal of Educational Research, 14(54), 61-78. https://doi.org/10.14689/ejer.2014.54.4 
Psympathic, Jurnal Ilmiah Psikologi Desember 2020, Vol. 7, No. 2, Hal. : 267-284 